\title{
Case report: a Chinese girl with dent disease 1 and turner syndrome due to a hemizygous CLCN5 gene mutation and Isochromosome $(\mathrm{Xq})$
}

\author{
Yuhong Ye ${ }^{1 \dagger}$, Jingjing Wang ${ }^{1 \dagger}$, Xiaofang Quan ${ }^{2}, \mathrm{Ke} \mathrm{Xu}^{2}$, Haidong $\mathrm{Fu}^{1}$, Weiyue $\mathrm{Gu}^{2^{*}}$ and Jianhua Mao ${ }^{{ }^{*}}$
}

\begin{abstract}
Background: Female Dent disease 1 patients with low-molecular-weight proteinuria (LMWP) due to CLCN5 gene mutation were rarely reported, and these cases that the people were also with Turner syndrome (TS) were even hardly documented before.

Case presentation: Here we report a 3-year and 11-month old Chinese girl with short stature who had a karyotype of $46, X, i(X)(q 10)$ and a de novo pathogenic variant in the CLCN5 gene on the short arm of X chromosome. Laboratory examinations showed that the patient had LMWP, hypercalciuria, hypophosphatemia, delayed bone age, and genital dysplasia.

Conclusion: The combination of $\mathrm{i}(\mathrm{X})(\mathrm{q} 10)$ and CLCN5 mutation causes the deletion of the wild-type CLCN5 allele that results in Dent- 1 and TS. To the best of our knowledge, this is the first case that a female CLCN5 mutation hemizygote is diagnosed with Dent-1 and Turner syndrome due to isochromosome X. Also, our case has indicated that the prevalence of the situation may be largely underestimated because of the mild signs of females with Dent-1.
\end{abstract}

Keywords: Dent disease 1, CLCN5, Turner syndrome, I(X)(q10), LMWP

\section{Background}

Dent disease 1 is a rare $\mathrm{X}$-linked recessive tubulopathy that occurs almost exclusively in males, and in the patients, mild structure abnormalities of proximal tubuli may cause kidney dysfunction. Pathogenic variant in the CLCN5 gene [1] is found in about $60 \%$ of Dent patients (Dent-1, MIM \# 300009), whereas OCRL gene 15\% (Dent2, MIM \# 300555). Dent-1 is characterized by LMWP, hypercalciuria, nephrocalcinosis, kidney stones, renal failure,

\footnotetext{
*Correspondence: gwyue@163.com; maojh88@zju.edu.cn

${ }^{\dagger}$ Ye Yuhong and Wang Jingjing are contributed equally to this study and are co-first author

${ }^{2}$ Chigene (Beijing) Translational Medical Research Center Co. Ltd., E2

Biomedical Park, \#88 Kechuang Sixth Ave, Yizhuang, Beijing, China

'Department of Nephrology, The Children's Hospital of Zhejiang University

School of Medicine, \#57 Zhugan Lane, Hangzhou 310003, China
}

and rickets [2]. LMWP is the most common phenotype in Dent- 1 patients and clinically identified by the elevated levels of urinal $\beta$-2-microglobulin $(\beta 2 \mathrm{M}), \quad \alpha-1$ microglobulin $(\alpha 1 \mathrm{M})$ and retinol-binding protein (RBP). Asymptomatic LMWP without nephrotic-range proteinuria (NP) may be observed in almost half of Japanese Dent-1 patients [3], which may indicates a racial specificity in the heterogeneity of Dent-1.

TS is one of the most common chromosomal disorders that affects approximately one in every $2500 \mathrm{fe}$ males [4]. The clinical features of TS largely depend on the involved regions of the X-chromosome and/or the pattern of X-structural abnormalities. Almost half of TS patients have a karyotype of $45, \mathrm{X}$, who usually manifests as the full TS phenotypes including short stature,

(c) The Author(s). 2020 Open Access This article is licensed under a Creative Commons Attribution 4.0 International License, which permits use, sharing, adaptation, distribution and reproduction in any medium or format, as long as you give appropriate credit to the original author(s) and the source, provide a link to the Creative Commons licence, and indicate if changes were made. The images or other third party material in this article are included in the article's Creative Commons licence, unless indicated otherwise in a credit line to the material. If material is not included in the article's Creative Commons licence and your intended use is not permitted by statutory regulation or exceeds the permitted use, you will need to obtain permission directly from the copyright holder. To view a copy of this licence, visit http://creativecommons.org/licenses/by/4.0/ The Creative Commons Public Domain Dedication waiver (http://creativecommons.org/publicdomain/zero/1.0/) applies to the data made available in this article, unless otherwise stated in a credit line to the data. 
ovarian insufficiency, skeletal dysplasia, heart defects, renal structural anomalies, characteristic facial abnormalities, etc. [4-6], whereas the partial X-structural abnormalities like ring $(\mathrm{X})$ or $\mathrm{i}(\mathrm{Xq})$, deletions, duplications and complex rearrangements may cause certain TS phenotypes $[7,8]$. However, abnormal $\mathrm{X}$ chromosomes can usually tolerate structural abnormalities due to preferential inactivation, which explains why TS patients with 45 , $\mathrm{X}$ karyotypes may have only mild clinical phenotypes [7].

Here we report a 3-year and 11-month old Chinese girl with unexplained proteinuria, who was diagnosed with heterozygous $\mathrm{i}(\mathrm{Xq})$ or TS and asymptomatic LMWP due to a "hemizygous" pathogenic variant in the CLCN5 gene on short arm of X chromosome.

\section{Case presentation}

The patient was admitted because of having abnormal urine test results when she was 3-year and 11-month old. Physical examination showed she had significant short stature of $93 \mathrm{~cm}$ in height $(-2 \mathrm{SD})$ and relatively lighter weight of $13.6 \mathrm{~kg}$. Neither other physical disorder nor dysmorphia detected. Her unrelated parents and elder sister are normal, and there is no family history of renal disorders.
Laboratory tests indicated that she had LMWP, hypercalciuria, hypophosphatemia, and growth hormone deficiency (Table 1). The results for tests parathyroid hormone, erythrocyte sedimentation rate (ESR), coagulation spectrum, ceruloplasmin, blood lead concentration, determination of trace elements, antinuclear antibodies (ANA), thyroid function, and cytokines by flow cytometry were normal. The renal biopsy was not performed.

Imaging studies: The renal ultrasound showed bilateral normal-sized kidneys for her age, and no evidence of calculus or nephrocalcinosis. The X-ray imaging indicated the delayed bone age, and the ultrasound scan showed the infantile uterus and bilateral absence of the ovaries.

Gene sequencing and Karyotyping: The trio copy number variation sequencing (CNV-seq), a HTS-based method for genome-wide CNV analyzing [9], showed a large de novo $\mathrm{CNV}$ on the $\mathrm{X}$ chromosome, a heterozygous loss of almost the whole $\mathrm{X}$ short arm and a heterozygous duplication of the rest region of the $\mathrm{X}$ chromosome (Fig. 1a, b). Karyotyping showed the patient has $\mathrm{i}(\mathrm{X})(\mathrm{q} 10)$ and $\operatorname{inv}(9)(\mathrm{p} 11 \mathrm{q} 13)$ pat (Fig. 1c). Using trio whole exome sequencing (WES), we identified a de novo variant NM_000084:c.941C > T, p.S314L in the CLCN5 gene on Xp (Fig. 1d), and Sanger sequencing confirmed the variant is de novo and "homozygous"

Table 1 Laboratory test results

\begin{tabular}{|c|c|c|c|c|}
\hline & Tests & At diagnosis & At 18 months follow up & Normal \\
\hline \multirow[t]{10}{*}{ Urine } & Total protein & $715.7 \mathrm{mg} / 24 \mathrm{~h}$ & $709 \mathrm{mg} / 24 \mathrm{~h}$ & $<150 \mathrm{mg} / 24 \mathrm{~h}$ \\
\hline & Total LMWP & 1270 mg/L & & \\
\hline & $\beta 2 \mathrm{M}$ & 25.77 mg/L & & $0-0.3 \mathrm{mg} / \mathrm{L}$ \\
\hline & a1M & $284.47 \mathrm{mg} / \mathrm{L}$ & & $<12 \mathrm{mg} / \mathrm{L}$ \\
\hline & Microalbumin & $245.3 \mathrm{mg} / \mathrm{L}$ & & $<30 \mathrm{mg} / \mathrm{L}$ \\
\hline & $\lg G$ & $41.8 \mathrm{mg} / \mathrm{L}$ & & $<10 \mathrm{mg} / \mathrm{L}$ \\
\hline & Transferrin & $28.3 \mathrm{mg} / \mathrm{L}$ & & $<2.4 \mathrm{mg} / \mathrm{L}$ \\
\hline & RBP & $13.7 \mathrm{mg} / \mathrm{L}$ & & $<0.5 \mathrm{mg} / \mathrm{L}$ \\
\hline & Calcium & $81.2,90.6 \mathrm{mg} / 24 \mathrm{~h}^{\mathrm{a}}$ & $93 \mathrm{mg} / 24 \mathrm{~h}$ & $100-300 \mathrm{mg} / 24 \mathrm{~h}$ \\
\hline & Calcium/creatinine ratio & $0.40,0.46^{\mathrm{a}}$ & 0.37 & $<0.14$ \\
\hline \multirow[t]{9}{*}{ Blood } & Calcium & $2.16 \mathrm{mmol} / \mathrm{L}$ & $2.37 \mathrm{mmol} / \mathrm{L}$ & $2.2-2.65 \mathrm{mmol} / \mathrm{L}$ \\
\hline & Creatinine & $38 \mu \mathrm{mol} / \mathrm{L}$ & $43 \mu \mathrm{mol} / \mathrm{L}$ & $\sim 44-133 \mu \mathrm{mol} / \mathrm{L}$ \\
\hline & Phosphorus & $1.25 \mathrm{mmol} / \mathrm{L}$ & $1.2 \mathrm{mmol} / \mathrm{L}$ & $1.29-2.26 \mathrm{mmol} / \mathrm{L}$ \\
\hline & $25(\mathrm{OH}) \mathrm{D}$ & $21.8 \mathrm{nmol} / \mathrm{L}$ & $18.4 \mathrm{nmol} / \mathrm{L}$ & $50-125 \mathrm{nmol} / \mathrm{L}$ \\
\hline & BAP & $<200$ & & $\sim 12.1-42.7$ \\
\hline & Peak level of GH & $6.4 \mathrm{ng} / \mathrm{ml}$ & & $>10 \mathrm{ng} / \mathrm{ml}$ \\
\hline & $\mathrm{LH}$ & $1.03 \mathrm{IU} / \mathrm{L}$ & & $<0.4 \mathrm{IU} / \mathrm{L}$ \\
\hline & FSH & $36.6 \mathrm{IU} / \mathrm{L}$ & & $0.5-3.2 \mathrm{IU} / \mathrm{L}$ \\
\hline & E2 & $100 \mathrm{pmol} / \mathrm{L}$ & & $<149.2 \mathrm{pmol} / \mathrm{L}$ \\
\hline
\end{tabular}

25(OH) D 25-hydroxy vitamin D, BAP Bone-specific alkaline phosphatase, E2 Estradiol, FSH Follicle-stimulating hormone, GH Growth hormone, IgG Immunoglobulin $\mathrm{G}$, LH Lutenizing hormone, LMWP Low molecular weight protamine, RBP Retinol binding protein, a1M a-1-microglobulin, $\beta 2 M ~ \beta-2$-microglobulin

${ }^{\text {a }}$ Results for the two tests 
A

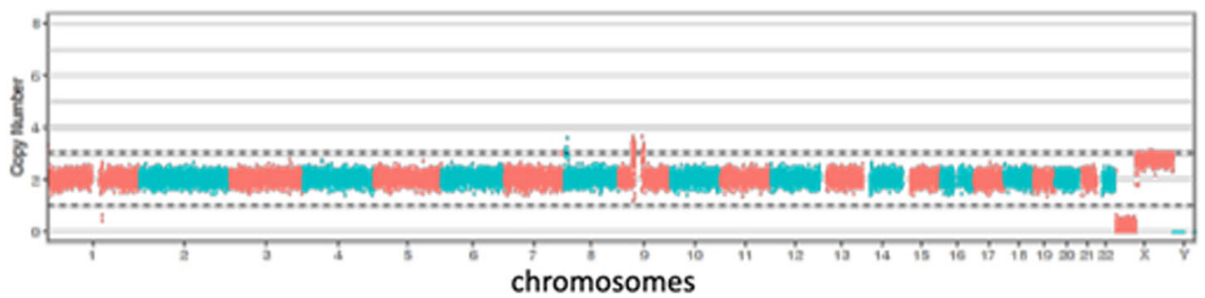

B

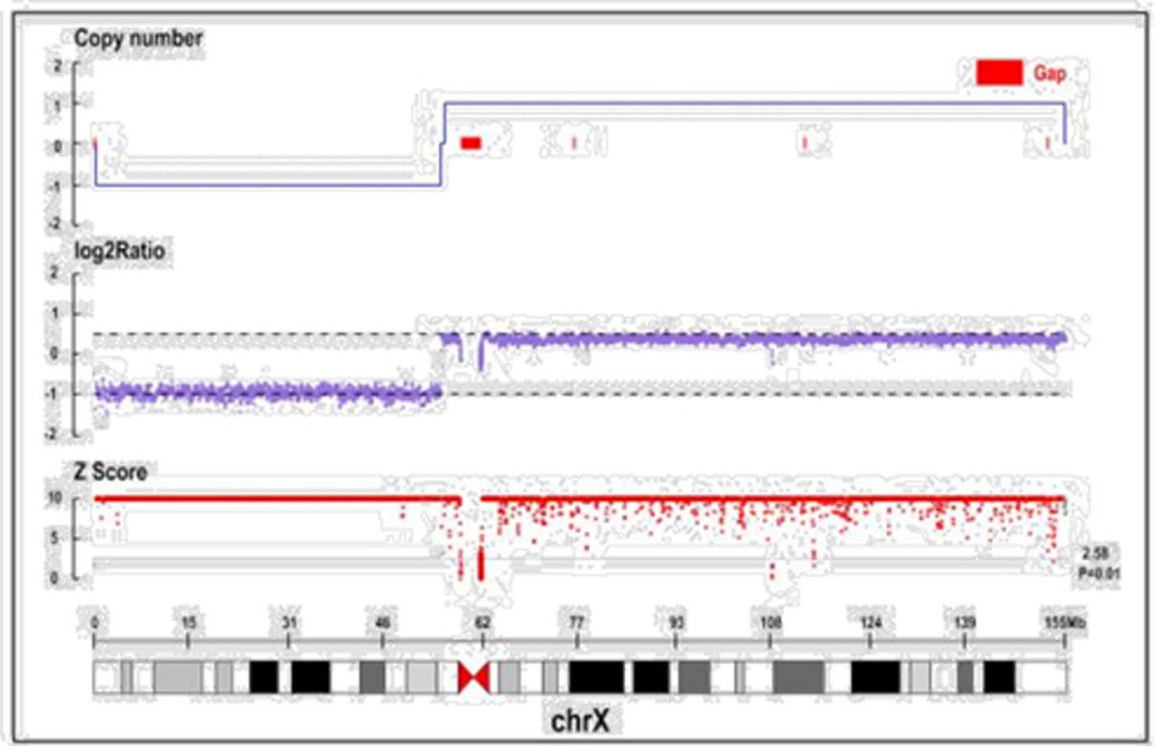

C

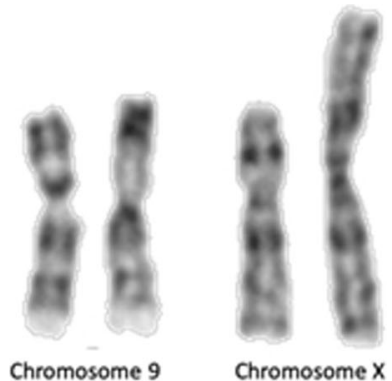

D

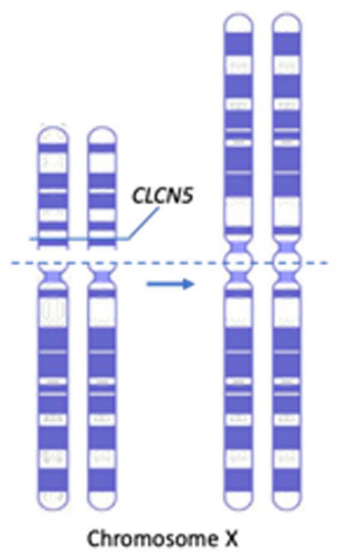

Fig. 1 Results of CNV-seq and variant chromosomes. a Whole genomic copy number sequencing revealed deletion and duplication of $X$ chromosome. $\mathbf{b}$ The result of $X$ chromosome copy number shows the heterozygous duplicated long-arm $q$ and the heterozygous deleted shortarm p. c Karyotype shows inv(9)(p11q13) pat and $i(X)(q 10)$. d A schematic representation of the $\mathrm{i}(\mathrm{Xq})$, and its cleavage/recombination site on one $X$ chromosome, where the CLCN5 gene is located on the short arms of $X$ chromosome

(Fig. 2). The variant S314L is pathogenic according to the ACMG (The American College of Medical Genetics and Genomics) clinical practice guidelines [10]. The defects in CUBN, the cubilin-coding gene, was reported the other single-gene cause of asymptomatic LMWP [11], which was excluded by pathogenic or likely pathogenic variant screening in our case. Using HUMARA method [12], X chromosome inactivation (XCI) test

De novo CLCN5 (NM_001127899) C.941 C $>$ T

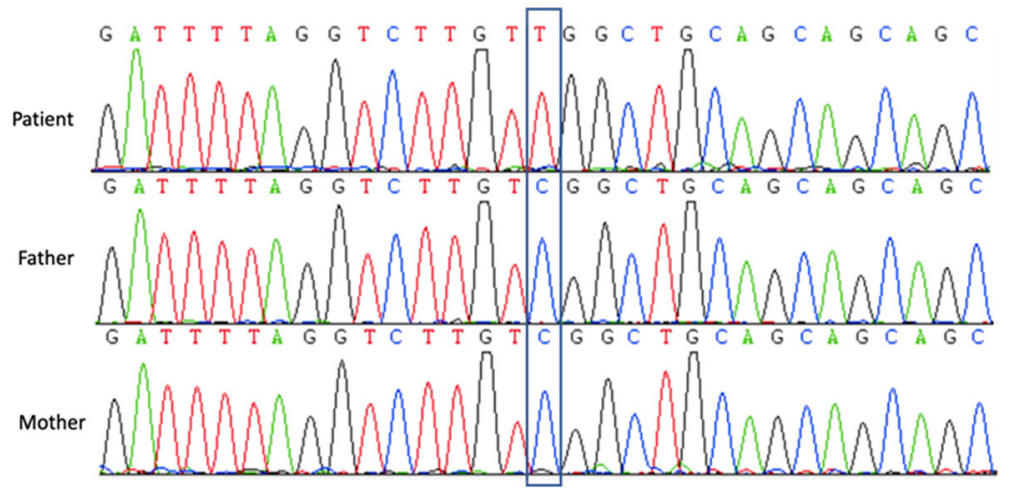

Fig. 2 Sanger sequencing confirm the de novo variant NM_000084:c.941C > T 
showed extremely skewed (98:2) inactivation of the $\mathrm{i}$ (Xq) chromosome.

Based on the above results, the patient was diagnosed with Dent disease 1 and Turner Syndrome. In the next 18 months, the child came to the clinic regularly for follow-up, and the condition was stable after examination (Table 1).

\section{Discussion and conclusions}

TS is a canonical knock-out model for studying $\mathrm{X}$ chromosome functions, and the most observed karyotype is the classic $45, \mathrm{X}(49.2 \%)$ followed by $46, \mathrm{X}, \mathrm{i}(\mathrm{Xq})$ or i (Xq) mosaic (9.8\%) in TS patients [13]. The specificity of phenotypes in TS patients largely depend on the involved regions and the patterns of variations of the $\mathrm{X}$ chromosome and the patients with i (Xq) may have specific signs of TS [7, 8]. Therman et al. [14] suggested that loss-of-short-arm X isochromosome is lethal because there is no method of dosage compensation, however, the beneficial effect of $\mathrm{X}$ inactivation may result in mild phenotypes in most patients with structural abnormalities of the $\mathrm{X}$ chromosome, which is similar to that found in TS patients with 45,X karyotype [7]. The heterogeneity of phenotypes in patients with $\mathrm{i}(\mathrm{Xq})$ due to extremely skewed $\mathrm{X}$ chromosome inactivation $(\mathrm{XCI})$ are still unclear and, in our patient, short stature and abnormal ovarian development are found.

Isochromosome $(\mathrm{Xq})$ are created by U-type strand exchange, a breakage and reunion in the centric or pericentric region of the $\mathrm{p}$ arm, or misdivision occurred in the pericentric region of the $\mathrm{p}$ arm, both result in dicentric $i(X q)$ and loss of the acentric $p$ arm [15]. Loss of the acentric Xp results in a partial monosomy of genes, CLCN5, for example, that locate in that portion of the acentric chromosome. (Fig. 1). The CLCN5-associated phenotypes may vary, expand from asymptomatic LMWP to severe skeletal dysplasia, and it should be noted that the most Dent-1 patients with asymptomatic proteinuria were reported in Japanese patients [3]. LMWP was defined as proteinuria with urinary proteins less than $40 \mathrm{kD}$ [16], which means the patients with isolated LMWP may not have NP. The other patients diagnosed with childhood-onset, isolated LMWP were reported in England [17], which suggests that this condition might not be confine to East Asian patients. Although Shogo Minamikawa et al. [18] demonstrated that the skewed XCI is responsible for some (two of four) of the affected females, it should be noticed that there may be potential heterogeneity of non-X-linked affection in hereditary LMWP patients since some of the fathers (of two of six) had significantly high frequencies of elevated levels of urinary $\beta 2 \mathrm{M}$.

Skewed XCI may play a random role in previously reported female Dent-1 cases [18] unless the occurrence can be explained by confirmed findings leading to XCI skewing, as in our patient. Though some studies indicated there may be the $\mathrm{X}$ control element (XCE), a ciselements to regulate $\mathrm{XCI}$, on the $\mathrm{X}$ chromosome [19, $20]$, as previously found in mice [21], there is no confirmed evidence of human XCE, yet. The X chromosome imprinting is a known cause of TS phenotypes, and GHstimulated heights of patients with imprinted maternal $\mathrm{X}$ are significantly shorter than patients with imprinted paternal X [22], which supports the findings in our case. The karyotype of inv(9)(p11q13) pat or other chromosome 9 variants like $9 \mathrm{qh}+, 9 \mathrm{cenh}+, 9 \mathrm{ph}+$, etc., is quite common in general population [23], and we did not find another chromosome 9 linked genetic variation associated with the phenotypes in our patient. Finally, the consistency of asymptomatic LMWP in Japanese and our patient suggests that LMWP is a stand-alone marker for prompting genetic testing in East Asian Dent-1 cases, and moreover, $\mathrm{CNV}$ or karyotype, and skewed XCI tests are needed to identify the potential defect of the $\mathrm{X}$ chromosome.

In Japanese Dent-1 cases, the patients with LMWP tended to have hypercalciuric nephrocalcinosis [24, 25], but the slow natural course of Dent-1 is a major obstacle to the follow-up study. For the further study, we recommend a large scale of a retrospective study in suspected Dent- 1 cases in China, since the prevalence of the disease in China may be largely underestimated because of the mild signs of female patients with Dent-1.

Unexplained LMWP is a sensitive marker for prompt genetic testing in East Asian patients. Our study in this unique, as far as we know, case expanded the spectrum of genotypes, phenotypes and racial specificity of Dent- 1 , and it raises a new issue to update the criteria for diagnosing Dent-1 disease in Chinese patients because the prevalence of Dent-1 in China might be underestimated.

\section{Abbreviations \\ ACMG: American College of Medical Genetics and Genomics; CNV-seq: Copy number variation sequencing; i $(X q)$ : Isochromosome $(X q)$; LMWP: Low- molecular-weight proteinuria; NP: Nephrotic-range proteinuria; RBP: Retinol- binding protein; TS: Turner syndrome; WES: Whole exome sequencing; XCE: $X$ control element; $X C I$ : $X$ chromosome inactivation; $X L R$ : $X$-linked

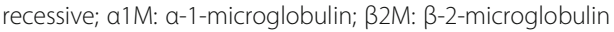

\section{Acknowledgements}

We thank the patient and her family for participating in this study.

\section{Authors' contributions}

YY, JW and HF carried out the analysis of the patient's clinical course and outcome, supported the clinical data collection, and analyzed the mutational data. XQ and WG provided the gene sequencing and analyzed the mutational data. KX and YY drafted the manuscript. JM established the diagnosis, revised and decided the final manuscript. All authors read and approved the final manuscript.

\section{Funding}

This study was supported by the National Natural Science Foundation of China (81470939 \& 81770710), the Specialized Research Fund for the Doctoral Program of Higher Education (20120101110018), the Natural 
Science Foundation of Zhejiang Province (LH14H050002\&LY15H050001) and the Medicine \& Health Technology Innovation Project of Zhejiang Province (2014KYA123). The funders had no role in study design, data collection and analysis, decision to publish, or preparation of the manuscript.

\section{Availability of data and materials}

The datasets used and/or analyzed during the current study are available from the corresponding author on reasonable request.

\section{Ethics approval and consent to participate}

The parents, who are legal guardians, of the patient had been informed about the availability and importance of genetic tests, including DNA and karyotyping, and the parents contented to the use of the anonymized test results and de-identified health information as described in this article.

\section{Consent for publication}

Written informed consent was obtained from the patient's parents for publication of this case report and any accompanying images. A copy of the written consent is available for review by the Editor of this journal.

\section{Competing interests}

The authors declare that they have no competing interests.

Received: 27 September 2019 Accepted: 22 April 2020

Published online: 11 May 2020

\section{References}

1. Lloyd SE, Pearce SH, Fisher SE, Steinmeyer K, Schwappach B, Scheinman SJ, et al. A common molecular basis for three inherited kidney stone diseases. Nature. 1996;379(6564):445-9.

2. Devonald MA, Karet FE. Renal epithelial traffic jams and one-way streets. J Am Soc Nephrol. 2004;15(6):1370-81.

3. Sekine T, Komoda F, Miura K, Takita J, Shimadzu M, Matsuyama T, et al. Japanese dent disease has a wider clinical spectrum than dent disease in Europe/USA: genetic and clinical studies of 86 unrelated patients with lowmolecular-weight proteinuria. Nephrol Dial Transplant. 2014;29(2):376-84.

4. Stochholm K, Juul S, Juel K, Naeraa RW, Gravholt CH. Prevalence, incidence, diagnostic delay, and mortality in turner syndrome. J Clin Endocrinol Metab. 2006;91(10):3897-902.

5. Gonzalez L, Witchel SF. The patient with turner syndrome: puberty and medical management concerns. Fertil Steril. 2012;98(4):780-6.

6. $\quad$ Sybert VP, McCauley E. Turner's syndrome. N Engl J Med. 2004;351(12):122738.

7. Leppig KA, Disteche CM. Ring X and other structural X chromosome abnormalities: X inactivation and phenotype. Semin Reprod Med. 2001;19(2): 147-57.

8. Ogata T, Matsuo N. Turner syndrome and female sex chromosome aberrations: deduction of the principal factors involved in the development of clinical features. Hum Genet. 1995;95(6):607-29.

9. Xie C, Tammi MT. CNV-seq, a new method to detect copy number variation using high-throughput sequencing. BMC Bioinformatics. 2009;10:80.

10. Richards S, Aziz N, Bale S, Bick D, Das S, Gastier-Foster J, et al. Standards and guidelines for the interpretation of sequence variants: a joint consensus recommendation of the American College of Medical Genetics and Genomics and the Association for Molecular Pathology. Genet Med. 2015; 17(5):405-24.

11. Ovunc B, Otto EA, Vega-Warner V, Saisawat P, Ashraf S, Ramaswami G, et al. Exome sequencing reveals cubilin mutation as a single-gene cause of proteinuria. J Am Soc Nephrol. 2011;22(10):1815-20.

12. Thouin MM, Giron JM, Hoffman EP. Detection of nonrandom $X$ chromosome inactivation. Curr Protoc Hum Genet. 2003;Chapter 9:Unit 9-7.

13. Gadhia P, Balar P, Gonawala T, Parekh N, Patel R, Vaniawala S. Cytogenetic study of Turner syndrome and its variants. Int J Hum Genet. 2014;14(3-4): $155-9$.

14. Therman E, Sarto GE, Patau K. Center for Barr body condensation on the proximal part of the human Xq: a hypothesis. Chromosoma. 1974;44(4):3616.

15. Wolff DJ, Miller AP, Van Dyke DL, Schwartz S, Willard HF. Molecular definition of breakpoints associated with human Xq isochromosomes: implications for mechanisms of formation. Am J Hum Genet. 1996;58(1): 154-60.
16. Suzuki Y, Okada T, Higuchi A, Mase D, Kobayashi O. Asymptomatic low molecular weight proteinuria: a report on 5 cases. Clin Nephrol. 1985;23(5): 249-54.

17. Geary DF, Dillon MJ, Gammon K, Barratt TM. Tubular proteinuria in children without other defects of renal function. Nephron. 1985;40(3):329-31.

18. Minamikawa S, Nozu K, Nozu Y, Yamamura T, Taniguchi-lkeda M, Nakanishi $K$, et al. Development of ultra-deep targeted RNA sequencing for analyzing X-chromosome inactivation in female dent disease. J Hum Genet. 2018; 63(5):589-95.

19. Renault NK, Pritchett SM, Howell RE, Greer WL, Sapienza C, Orstavik KH, et al. Human X-chromosome inactivation pattern distributions fit a model of genetically influenced choice better than models of completely random choice. Eur J Hum Genet. 2013;21(12):1396-402.

20. Amos-Landgraf JM, Cottle A, Plenge RM, Friez M, Schwartz CE, Longshore J, et al. X chromosome-inactivation patterns of 1,005 phenotypically unaffected females. Am J Hum Genet. 2006;79(3):493-9.

21. Cattanach $\mathrm{BM}$, Isaacson $\mathrm{JH}$. Controlling elements in the mouse $X$ chromosome. Genetics. 1967;57(2):331-46.

22. Hamelin CE, Anglin G, Quigley CA, Deal CL. Genomic imprinting in turner syndrome: effects on response to growth hormone and on risk of sensorineural hearing loss. J Clin Endocrinol Metab. 2006;91(8):3002-10.

23. Colls P, Blanco J, Martinez-Pasarell O, Vidal F, Egozcue J, Marquez C, et al. Chromosome segregation in a man heterozygous for a pericentric inversion, inv (9)(p11q13), analyzed by using sperm karyotyping and twocolor fluorescence in situ hybridization on sperm nuclei. Hum Genet. 1997; 99(6):761-5.

24. Igarashi $T$, Hayakawa $H$, Shiraga $H$, Kawato H, Yan K, Kawaguchi H, et al. Hypercalciuria and nephrocalcinosis in patients with idiopathic lowmolecular-weight proteinuria in Japan: is the disease identical to Dent's disease in United Kingdom? Nephron. 1995;69(3):242-7.

25. Akuta N, Lloyd SE, Igarashi T, Shiraga H, Matsuyama T, Yokoro S, et al. Mutations of CLCN5 in Japanese children with idiopathic low molecular weight proteinuria, hypercalciuria and nephrocalcinosis. Kidney Int. 1997; 52(4):911-6

\section{Publisher's Note}

Springer Nature remains neutral with regard to jurisdictional claims in published maps and institutional affiliations.
Ready to submit your research? Choose BMC and benefit from:

- fast, convenient online submission

- thorough peer review by experienced researchers in your field

- rapid publication on acceptance

- support for research data, including large and complex data types

- gold Open Access which fosters wider collaboration and increased citations

- maximum visibility for your research: over $100 \mathrm{M}$ website views per year

At $\mathrm{BMC}$, research is always in progress.

Learn more biomedcentral.com/submissions 